\title{
Evaluation of the Use of Jadelle Contraceptive Implant by Women in the City of Parakou in 2016
}

\author{
M. V. Vodouhe', K. Salifou ${ }^{1}$, A. Djidonou ${ }^{2}$, P. Degbogbahoun ${ }^{2}$, \\ I. R. Sidi' ${ }^{1}$, O. M. Ogoudjobi ${ }^{3}$, S. Adisso ${ }^{3}$, B. Hounkpatin ${ }^{2}$ \\ ${ }^{1}$ Mother and Child Department, Faculty of Medicine, University of Parakou, Parakou, Benin \\ ${ }^{2}$ Mother and Child Department, Faculty of Health Sciences, University of Abomey-Calavi, Abomey-Calavi, Benin \\ ${ }^{3}$ Psychiatric Service, Departmental Teaching Hospital of Borgou and Alibori, Parakou, Benin \\ Email: *salifoukabibou@yahoo.com
}

How to cite this paper: Vodouhe, M.V., Salifou, K., Djidonou, A., Degbogbahoun, P., Sidi, I.R., Ogoudjobi, O.M., Adisso, S. and Hounkpatin, B. (2018) Evaluation of the Use of Jadelle Contraceptive Implant by Women in the City of Parakou in 2016. Open Journal of Obstetrics and Gynecology, 8, 1487-1500.

https://doi.org/10.4236/ojog.2018.814150

Received: October 28, 2018

Accepted: December 3, 2018

Published: December 7, 2018

Copyright $\odot 2018$ by authors and Scientific Research Publishing Inc. This work is licensed under the Creative Commons Attribution International License (CC BY 4.0).

http://creativecommons.org/licenses/by/4.0/

\begin{abstract}
Introduction: Maternal mortality is still very high in Benin. Being one of the methods of reducing this mortality, contraception is still very rarely used in Benin, particularly in Borgou district. The objective of this work was to evaluate the experience of using Jadelle contraceptive implants by women in the city of Parakou in the Borgou department. Methodology: This was a descriptive cross-sectional study, with retrospective and prospective data collection over the period from March 1 to July 31, 2016. Results: A total of 320 women were involved in the study. The mean age was 28.29 years, with extremes of 16 and 44 years. Socio-professionally, housewives predominated (56.88\%). Sixty-eight point forty-four percent of women were educated and only 111 (34.69\%) women had reached secondary school; married women were mostly represented. Obstetrically, multi-gestures were the most affected (43.75\%). Birth spacing was the main reason for choosing Jadelle (48.13\%). Majority of patients had their husbands consent to use Jadelle contraceptive method (85.31\%). Sixty-eight point fifty-two percent of women had used this contraceptive method for 2 to 4 years. Jadelle had been chosen by the majority (78.75\%) of the women, for its long duration of action and its easy use. The dropout rate for Jadelle was $35 / 320(10.94 \%)$ after 3 years of use. The failure rate for this method was $0.31 \%(1 / 320)$. The satisfaction rate was $87.5 \%$. Conclusion: Jadelle contraceptive implants are an important part of contraceptive methods in Parakou.
\end{abstract}

\section{Keywords}

Contraceptive Method, Jadelle, Parakou, Benin 


\section{Introduction}

By spacing births and reducing the frequency of miscarriages, the use of this contraception makes it possible both to reduce the high rate of maternal mortality in emerging countries (10 to 70/10,000 versus $3 / 10,000$ in developed countries) and also infant mortality (113/1000 in Africa versus 12/1000 in Europe) [1]. The Benin Demographic and Health Survey (EDSB-IV) indicate high fertility rate (4.9 children per woman), a high rate of children and many early pregnancies (37\%) [2]. In recent years, less restrictive modern contraceptive methods have been developed, including progestin implants. Contraceptive prevalence rate is low in Benin (12.5\%), with $8 \%$ for modern methods [2]. The contraceptive implant, using a progestogen derivative as the active ingredient, has raised hope for interesting effective contraception to women who have a contraindication or intolerance to estrogen-progestogen pill or Intrauterine Device (IUD). Among these implants, the so-called new generation Jadelle implants have been marketed from the United States since 1996. These are 2-stick implants, each containing $75 \mathrm{mg}$ of Levonorgestrel, manufactured using new chemical proceeds. These implants are effective for 5 years [3]. However, its prescription can only be considered in the light of its tolerance. A study reported $27 \%$ removal of contraceptive implants before the end of the expiry date of contraceptive effectiveness. The bad experiences with progestin implants recorded in the literature concern mainly women in developed countries. There are few studies in Africa on this issue.

The situation in Borgou district seems very worrying. Indeed, the Demographic and Health Survey in Benin reveals that this district has the highest fertility rate in Benin (4.9 children per woman with an index of 5.4 in rural areas) [2]. Modern contraceptive methods, particularly progestin-only implants, are rarely used (1.1\%) by women in this department [2]. Through this work, we therefore suggest to evaluate the use of Jadelle contraceptive implants by women in Parakou, a town in the department of Borgou in Benin.

\section{Method}

This is a descriptive cross-sectional study over a period of 5 months from March 1 to July $31,2016$.

\subsection{Study Population}

The study population consists exclusively of women who have used Jadelle contraceptive implants at least once in their lifetime. These are patients who have consulted one of the Health Centres (HCs) in the city of Parakou: the Communal Health Centre (CHC) of Parakou, the HCs of Madina, Kpébié and Zongo.

- Involment criteria: The women involved in the study were women who had used Jadelle implant at least once in their lifetime, with the age group of 15 to 45 years and physical present on the day of the survey.

- Rejection criteria: The Women with major mental disorders were excluded 
from the study

\subsection{Sampling}

The minimum sample size was calculated by the SCHWARTZ formula $n=\frac{Z \alpha^{2} * p^{*}(1-p)}{i^{2}}$

$n=$ minimum number of women to be surveyed, $z=$ risk reduced deviation $\alpha$ (1.96), p: $7.9 \%$ contraceptive prevalence in Benin in 2011 [4], $q=1-p=$ $92.1 \%, i=3 \%$ (desired accuracy for our results), $\mathrm{n}=310.57$ That was 311 women to be investigated. The sampling technique used was exhaustive recruitment.

\subsection{Data Collection}

The information was collected by a documentary review using a tabulation form that concerned the medical files; supplemented by an individual "investigator-investigated" interview.

\subsection{Variables}

The variables studied were: age, sex, level of education, ethnicity, religion, marital status, background, type of contraception previously used, gestational age, parity, desire for pregnancy, duration of using Jadelle implants, Jadelle implant side effects, patients satisfaction. Satisfaction was assessed by the law of all or nothing: it was coded yes/no.

Any woman who had used subcutaneous Jadelle implants at least once was considered a user of Jadelle.

The potential patient is a woman who attends a health center at the request of a family planning service: information, contraceptive prescription, insertion or withdrawal, follow-up or other services. Abandonment: Abandoning a contraceptive method is synonymous with stopping its use for any other reason than the desire for maternity or the expiry of the time limit for using the method.

The failure rate of a contraceptive method is the number of pregnancies contracted out of the total number of users of that method during a given period.

The duration of effectiveness of Jadelle implants is five years.

\subsection{Data Processing and Analysis}

The data entry was made using the EPI DATA 3.1 French version. The data were then analyzed using EPI INFO version 7 software. Text processing, tables and graphs were made possible thanks to Microsoft Word and Excel version 2010. Quantitative variables are expressed as means with their standard deviation and qualitative variables as proportions with their confidence interval.

\subsection{Ethical Considerations}

We obtained the agreement of the Departmental Director of Health of Borgou and Alibori and the managers of the various centers where we conducted the 
study. Participants received detailed information about the study and agreed to participate. Data collection procedures were in accordance with the ethical principles contained in the Declaration of the World Medical Association of Helsinki.

\section{Results}

\subsection{Socio-Demographic Characteristics (Table 1)}

In total, 320 women were involved in our study with a mean age of 28.29 years

Table 1. Socio-demographic characteristics of patients.

\begin{tabular}{|c|c|c|}
\hline & Effective & $\%$ \\
\hline \multicolumn{3}{|l|}{ Age } \\
\hline$\leq 19$ & 29 & 9.06 \\
\hline $20-29$ & 152 & 47.5 \\
\hline $29-39$ & 118 & 36.88 \\
\hline $39-44$ & 21 & 6.56 \\
\hline \multicolumn{3}{|l|}{ Marital status } \\
\hline Married & 277 & 86.56 \\
\hline Single & 43 & 13.44 \\
\hline \multicolumn{3}{|l|}{ Profession } \\
\hline Housewives & 182 & 56.88 \\
\hline Liberal & 86 & 26.87 \\
\hline Pupil / Student & 28 & 8.75 \\
\hline Employee & 24 & 7.5 \\
\hline \multicolumn{3}{|l|}{ School level } \\
\hline Not in school & 101 & 31.56 \\
\hline Primary school & 96 & 30 \\
\hline Secondary school & 111 & 34.69 \\
\hline Academic & 12 & 3.75 \\
\hline \multicolumn{3}{|l|}{ Religion } \\
\hline Muslim & 190 & 59.38 \\
\hline Christian & 116 & 36.25 \\
\hline Endogenous religion & 14 & 4.37 \\
\hline \multicolumn{3}{|l|}{ Parity } \\
\hline Nulliparous & 19 & 5.94 \\
\hline Primiparous & 57 & 17.81 \\
\hline Pauciparous (2 - 3) & 106 & 33.13 \\
\hline Multiparous (4) & 82 & 25.62 \\
\hline Large multiparous & 56 & 17.5 \\
\hline
\end{tabular}


and extremes of 16 and 44 years. There was a higher frequency of pauciparous. Moreover $12.50 \%$ of our patients had a history of wanted Pregnancy Interruption (VPI), and the average number of living children was 3.17.

\subsection{Reasons for Contraception}

The need for contraception was motivated by spacing birth for $85.64 \%$ of patients. Table 2 shows the distribution of patients by reasons for choosing Jadelle contraception. Fourteen point sixty nine percent of patients had not obtained their husband consent.

\subsection{Sources of Information}

Figure 1 shows the distribution of patients by their main source of information on Jadelle implants. Midwives were the primary source of information for patients.

\subsection{Previous Contraceptive Methods}

Before Jadelle implants, $81.25 \%$ of patients did not have a contraceptive method;

Table 2. Patients motivation for Jadelle contraception (one choice possible).

\begin{tabular}{ccc}
\hline & Effective & $\%$ \\
\hline $\begin{array}{c}\text { Long and loosely constraining contraception } \\
\text { Contraindications to IUDs or OPs }\end{array}$ & 261 & 82.56 \\
Information & 4 & 1.25 \\
- a health worker & 44 & 13.74 \\
- the media or a friend & 6 & 1.88 \\
Other & 5 & 1.56 \\
Total & 320 & 100
\end{tabular}

OP: Oestroprogestative; IUD: Intrauterine Device.

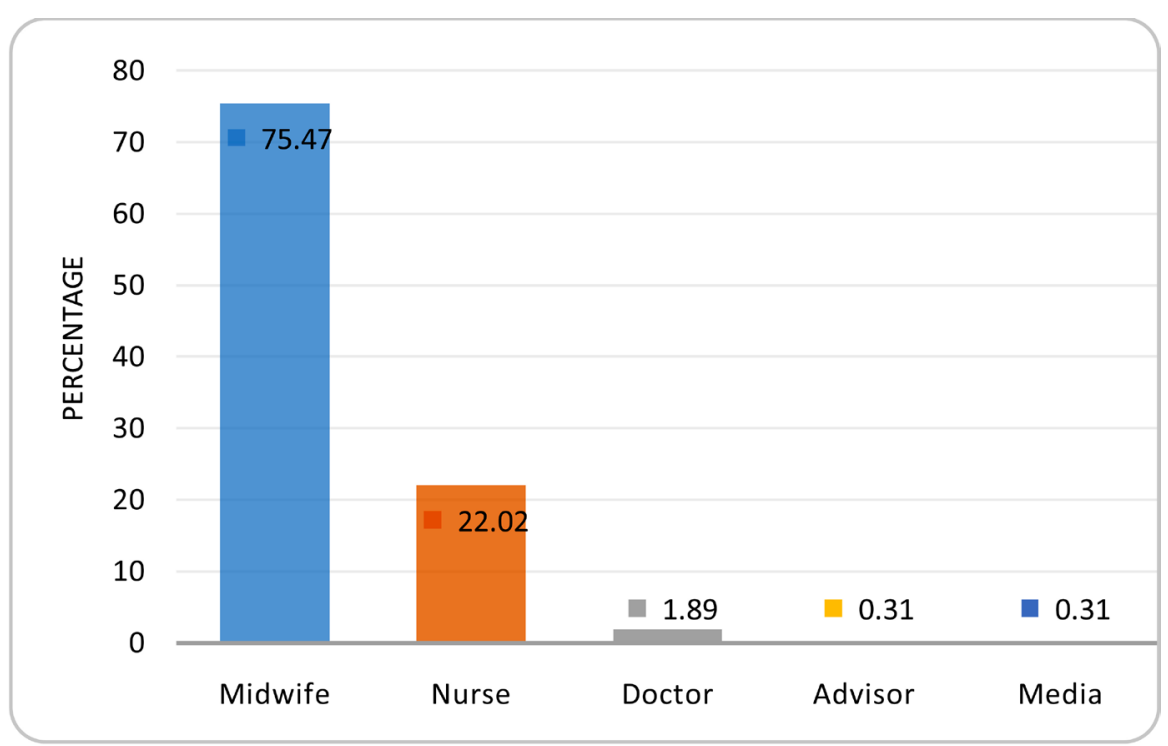

Figure 1. Distribution of patients by information sources. 
Figure 2 shows the distribution of patients by previous contraceptive methods.

\subsection{Side Effects of Jadelle}

Table 3 shows the distribution of patients according to the side effects of Jadelle. A high proportion of patients $(70 ; 21.87 \%)$ reported side effects, with a predominance of menstrual cycle disorders (pelvic pain during menstruation, amenorrhea, hyper-menorrhea, hypo-menorrhea). Amenorrhea were the most common menstrual cycle disorders observed (19; 5.94\%); we recorded 2 (0.63\%) cases of infection of Jadelle implant insertion site.

\subsection{Wear Duration of Jadelle}

Average duration of Jadelle use was 42.39 months with extremes of 11 and 72 months. Figure 3 shows the distribution of patients by duration of Jadelle implants.

\subsection{Reasons for Jadelle Withdrawal}

One hundred and thirty-seven patients had their jadelle implants removed. There were 51 (15.94\%) cases of abandonment: side effects (40); husband opposition (4); religious reasons (5); discomfort (1); change of contraceptive method (1). The proportion of abandonment was $11 / 320(3.45 \%)$ at 1 year and $35 / 320$ (10.94\%) at 3 years; Table 4 shows the distribution of patients according to the reasons for implant removal. We recorded one case of pregnancy despite the placement of Jadelle implants, which represents a failure rate of $0.31 \%$.

\subsection{Patients Satisfaction}

Two hundred and eighty (87.5\%) patients were generally satisfied and had agreed to counsel their family and friends.

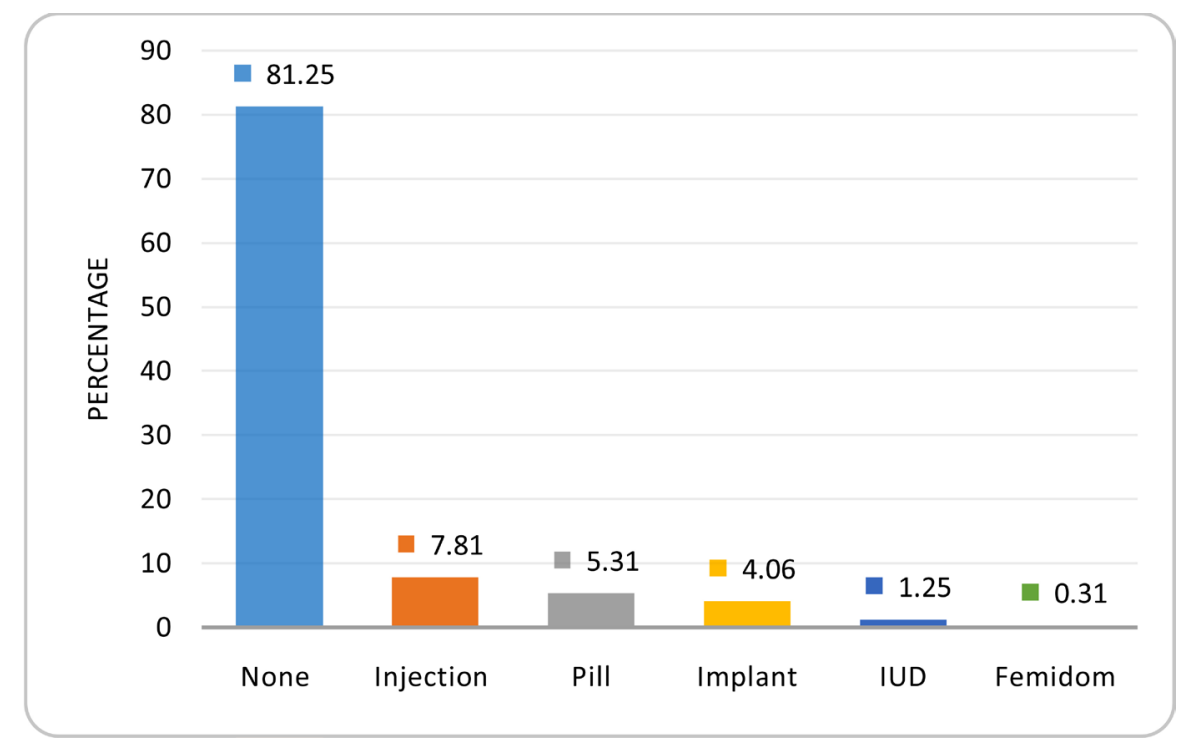

Figure 2. Distribution of patients by previous contraceptive methods used. 
Table 3. Patients distribution by Jadelle's side effects.

\begin{tabular}{|c|c|c|c|}
\hline Side effects & Effective & Percentage & $\mathrm{IC}_{95 \%}$ \\
\hline \multicolumn{4}{|l|}{ HTA } \\
\hline Yes & 4 & 1.25 & $0.40-3.39$ \\
\hline No & 316 & 98.75 & $96.61-99.60$ \\
\hline \multicolumn{4}{|l|}{ Headaches } \\
\hline Yes & 3 & 0.94 & $0.24-2.95$ \\
\hline No & 317 & 99.06 & $97.05-99.76$ \\
\hline \multicolumn{4}{|l|}{ Pelvic pain } \\
\hline Yes & 20 & 6.25 & $3.96-10.10$ \\
\hline No & 300 & 93.75 & $89.61-97.60$ \\
\hline \multicolumn{4}{|l|}{ Breast pain } \\
\hline Yes & 2 & 0.62 & $0.11-2.49$ \\
\hline No & 318 & 99.38 & $97.51-99.89$ \\
\hline \multicolumn{4}{|c|}{ Pain at the insertion site } \\
\hline Yes & 2 & 0.62 & $0.11-2.49$ \\
\hline No & 318 & 99.38 & $97.51-99.89$ \\
\hline \multicolumn{4}{|l|}{ Amenorrhea } \\
\hline Yes & 19 & 5.94 & $2.64-9.89$ \\
\hline No & 301 & 94.06 & $91.27-97.68$ \\
\hline \multicolumn{4}{|l|}{ Acne } \\
\hline Yes & 2 & 0.62 & $0.11-2.49$ \\
\hline No & 318 & 99.38 & $97.51-99.89$ \\
\hline \multicolumn{4}{|c|}{ Hypermenorrhea } \\
\hline Yes & 4 & 1.25 & $0.40-3.39$ \\
\hline No & 316 & 98.75 & $96.61-99.60$ \\
\hline \multicolumn{4}{|c|}{ Hypomenorrhea } \\
\hline Yes & 2 & 0.62 & $0.11-2.49$ \\
\hline No & 318 & 99.38 & $97.51-99.89$ \\
\hline \multicolumn{4}{|l|}{ Weight gain } \\
\hline Yes & 8 & 2.50 & $5.86-12.37$ \\
\hline No & 312 & 97.50 & $95.73-99.05$ \\
\hline \multicolumn{4}{|l|}{ Hot flush } \\
\hline Yes & 3 & 0.94 & $0.24-2.95$ \\
\hline No & 317 & 99.06 & $97.05-99.76$ \\
\hline \multicolumn{4}{|l|}{ Others } \\
\hline Yes & 3 & 0.94 & $0.24-2.95$ \\
\hline No & 317 & 99.06 & $97.05-99.76$ \\
\hline
\end{tabular}

Others: nervousness 1 vertigo 1 Spaniomenorrhea 1. 


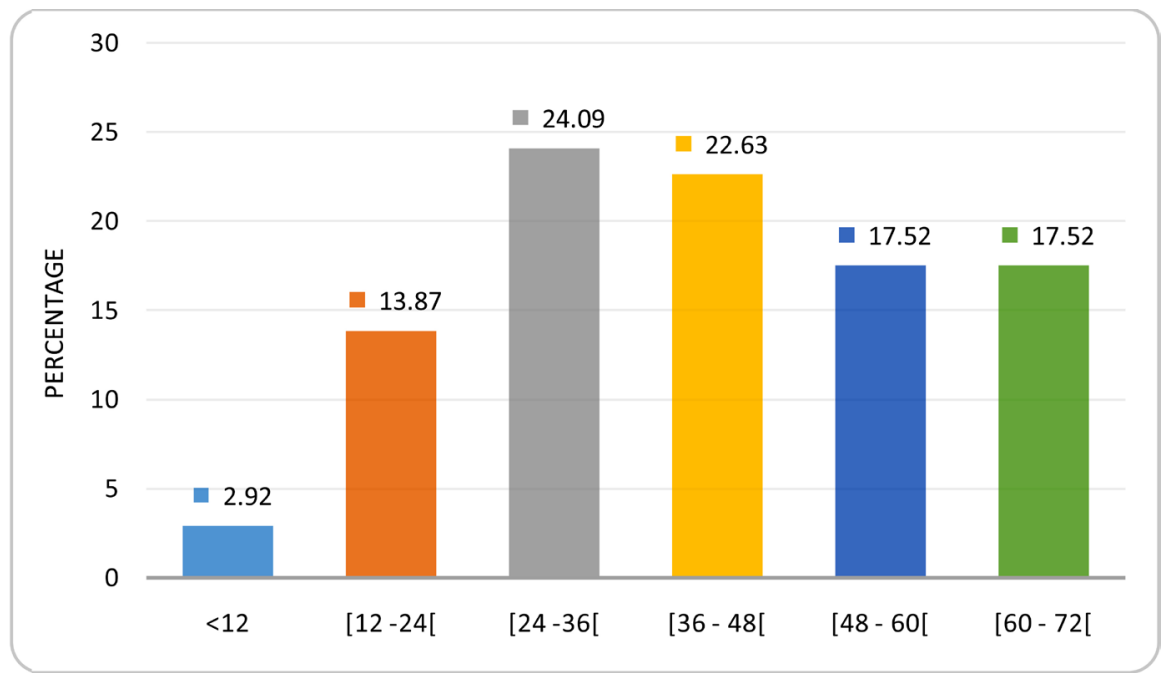

Figure 3. Distribution of patients by duration use of Jadelle implants.

Table 4. Distribution of patients by reason for Jadelle implants removal.

\begin{tabular}{ccc}
\hline & Effective & $\%$ \\
\hline Desire for pregnancy & 66 & 48.18 \\
Side Effects & 40 & 29.20 \\
Expiry of effectiveness & 19 & 14.60 \\
Change of contraceptive method & 1 & 0.73 \\
Discomfort & 1 & 0.73 \\
Husband opposition & 4 & 2.91 \\
Religious reason & 5 & 3.65 \\
Pregnancy & 1 & 0.73 \\
Total & 137 & 100 \\
\hline
\end{tabular}

\section{Discussion}

Participants mean age in our study was 28.29 years. This result is similar to those of Sergeant [3], Kouakou [5], and Adetoro [6] who reported an average age of 28 years. However, other authors have found a mean age of 32 years higher than that of our series. The 20 - 29 age group was the most represented in our series (47.50\%). Martin [7] in France, had noted a predominance of the 20 to 25 age group. These results show that younger women are particularly interested in contraceptive implants.

The Muslim religion predominated in our series (59.38\%). But this religious configuration is similar to that of the city of Parakou where she resides. Argina [8] had obtained a predominance of the Christian religion in her series. Despite the reluctance of some religions, it could be said that religion has little influence on the use of contraceptive implants.

Married women were in majority represented (86.56\%) in our series. This result is close to that of Ralisata [9]. Married women have more or less regular 
sexual relations and seem to be aware of their high risk of pregnancy... Housewives were the most represented in our series (56.88\%). This result is similar to that reported by some authors [9] [10].

Multiparous women were mainly represented (43.13\%) among our patients. Multiparity was also predominant in some studies [9] [10]. These observations could be justified by the fact that women with children would be more inclined to birth spacing due to their difficulties, but $5.63 \%$ of Jadelle users in our series were nulligest: This shows that this contraceptive method is not limited to women with children.

More than $10 \%$ of our Jadelle users had a history of wanted pregnancy interruption (abortion). This proportion is lower than that obtained by Ralisata [9] (45.40\%). This history of abortion may justify the choice of a long-term contraceptive method such as Jadelle so as not to have to make a radical and risky choice such as abortion.

Most of the spouses (85.31\%) of our patients were consenting to the use of Jadelle implants by their wives. The lack of access to good information on different contraceptive methods could justify the hostility of some men, hence the usefulness of strengthening the different means of raising awareness among the population.

A high proportion of patients $(70 ; 21.87 \%)$ reported side effects, with amenorrhea predominating (5.94\%), Igwe [11] in Nigeria and Bitzer [12] in Switzerland also reported higher proportions of amenorrhea under contraceptive implants, $58.8 \%$ and $33 \%$ respectively. Some studies report the prevalence of other bleeding disorders under contraceptive implants: spotting (54.70\%) in Senegal [13], irregular bleeding (27\%) in Belgium [14]. In our study, we observed a small proportion of side effects unrelated to the menstrual cycle under Jadelle. Similar results have been reported by Lankoande [15] and Croxatto [16].

Complications at the insertion site of Jadelle implants were rare. In contrast, in the United States in 1995, Wysowski [17] reported 24 women hospitalized for infectious complications. The occurrence of complications from the implant insertion site would in most cases be related to the competence of the providers and the asepsis conditions.

Jadelle implants average duration was 42.39 months in our study. This duration is higher than those reported by Argina [8] in Ethiopia and Dugoff [18] in the United States respectively 25.3 months and 13.2 months. Maternity was the main reason for removing Jadelle implants for our patients $(48.18 \%)$. This result is similar to those of Champootaweep [19], and Igwe [11]. Like Musham [20] in the United States, in our serie, side effects were the first reason for abandoning Jadelle (29.20\%). Sihvo [21] in Finland had reported cases of Jadelle abandonment for depression and nervousness. The drop-out rate was $10.94 \%$ at 3 years in our series. This rate is lower than that reported by Sergent [3] in France: 30\% before 2 years. Contraceptive implants seem to be better tolerated by women in Benin. Other prospective follow-up studies, after the insertion of Jadelles, will 
certainly be able to better inform us on the issue.

We noted a failure rate of $0.31 \%$ in our study. Koné [10] had objectified 2 cases of pregnancy in patients who were on anti-tuberculosis drugs. In view of all this, we could say that Jadelle remains an effective and acceptable contraceptive method. Most of our patient under Jadelle were satisfied (87.5\%) and had agreed to recommand it to their family and friends. Sergeant [3] reported a dissatisfaction rate of $81 \%$, lower than that in our study, and according to our results Jadelle users were predominantly educated (68.44\%). Hodonou [22] had reported the positive attitude of married teachers towards contraception. Sépou [23] had also shown that there was a significant relationship between educational level and contraceptive use. Most health information and awareness is provided in French and therefore requires a certain level of education to be understood.

One of the limitations of our study was that it was partly retrospective, leading to information bias. Moreover, not all users of Jadelle implants were interviewed.

\section{Conclusion}

Jadelle's users are young. Most of them had never used a contraceptive method previously. Side effects were rare and dominated by menstrual disorders typed amenorrhea. Most of them were satisfied.

\section{Conflicts of Interest}

The authors declare no conflicts of interest regarding the publication of this paper.

\section{References}

[1] Lansac, J., Lecomte, P. and Marret, H. (2012) Gynécologie pour le praticien. Issy-les-Moulineaux, Elsevier Masson SAS.

[2] Institut National de la Statistique et de l'Analyse Economique. (2012) Enquête démogra-phique et de santé et à indicateurs multiples du Bénin EDS-MICS-IV, 2011-2012: Rapport préliminaire.

https://www.researchgate.net/publication/259999730_Enquete_Demographique_et_ de_Sante_et_a_Indicateurs_Multiples_du_Benin_EDS-MICS-IV_2011-2012_Rappo $\underline{\text { rt_Preliminaire }}$

[3] Sergent, F., Clamageran Bastard, A.-M., Verspyck, E. and Marpeau, L. (2004) Acceptabilité de l'implant contraceptif à l'étonogestrel (Implanon). Journal de Gynécologie Obstétrique et Biologie de la Reproduction, 33, 407-415. https://doi.org/10.1016/S0368-2315(04)96548-9

[4] Ministère de la santé Bénin (2013) Plan d'action national budgétisé pour le repositionnement de la planification familiale 2014-2018 au Bénin. https://www.healthpolicyproject.com/ns/docs/CIP_Benin.pdf

[5] Kouagou, K.P., Doumbia, Y., Djanhan, L.E., Menin, M.M., Téhé, T.J., et al. (2009) Expérience d'introduction de l'implant contraceptif Jadelle en Côte d'Ivoire: Analyse de l'efficacité, des incidents et des effets indésirables chez 300 femmes. Clinics in Mother and Child Health, 6, 1095-1099. https://www.ajol.info/index.php/cmch/article/view/54324/42843

[6] Adetero, O.O. and Anate, M. (1988) Family Planning Practice among Nigerian Stu- 
dent Midwives. International Journal of Gynecology \& Obstetrics, 27, 415-420. https://doi.org/10.1016/0020-7292(88)90123-3

[7] Martin, C., Tanguy, M., Aspeele, F. and Fanello, S. (2010) Evaluation de la tolérance de l'implant contraceptif selon le contexte de prescription (post-IVG ou non): Étude prospective chez 127 patientes. Journal de Gynécologie Obstétrique et Biologie de la Reproduction, 39, 632-636. http://www.em-consulte.com/en/article/272601 https://doi.org/10.1016/j.jgyn.2010.09.005

[8] Argina, H. and Lukman, H.Y. (1997) Norplant Implants in Ethiopia. East African Medical Journal, 74, 258-262. https://www.ncbi.nlm.nih.gov/pubmed/9299831

[9] Ralisata, R.L., Randaoharison, P.G. and Razafintsalama, D.L. (2000) La contraception par les implants sous-cutanés de Levonorgestrel (NORPLANT) au CHU de Mahajanga Madagascar: Résultats préliminaires. Médecine d'Afrique Noire, 47, 410-415. http://www.santetropicale.com/Resume/104702.pdf

[10] Kone, B., Lankoande, J., Ouédraogo, C.M.R., Ouédraogo, A., Bonane, B., et al. (1999) La contraception par les implants sous-cutanés de Levonorgestrel (Norplant $\left.{ }^{\circledR}\right)$; Expérience africaine du Burkina Faso. Médecine d'Afrique Noire, 46, 136-139. http://www.santetropicale.com/Resume/34602.pdf

[11] Igwe, M.N., Ejikeme, B.N. and Agboeze, J.J. (2016) A 5-Year Clinical Evaluation of Subdermal Implants Among Abakaliki. Journal of Basic and Clinical Reproductive Sciences, 5, 1-5. http://www.jbcrs.org https://doi.org/10.4103/2278-960X.175730

[12] Bitzer, J., Tschudin, S., Alder, J. and Swiss, I.S.G. (2004) Acceptability and Side-Effects of Implanon in Switzerland: A Retrospective Study by the Implanon Swiss Study Group. The European Journal of Contraception \& Reproductive Health Care, 9, 278-284. https://www.ncbi.nlm.nih.gov/pubmed/15799185 https://doi.org/10.1080/13625180400017503

[13] Diop, S.N., Gueye Ba, M., Tall, A. and Diadhiou, F. (2003) Les implants contraceptifs Norplant ${ }^{\mathbb{R}}$ : Evaluation des effets secondaires, du poids et de la tension artérielle dans 3 cliniques de planification familiale à Dakar (Sénégal). Journal de Gynécologie Obstétrique et Biologie de la Reproduction, 32, 246-251.

[14] Vekemans, M., Delvigne, A. and Paesmans, M. (1996) Continuité d'utilisation d'un implant contraceptif au Lévonorgestrel: Etude prospective en Belgique. Revue médicale de Bruxelles, 17, 375-381. http://www.bdsp.ehesp.fr/Base/137795/

[15] Lankoande, J., Ouedrago, A., Dao, B., Ouedraogo, C.M., Bonane, B., Toure, B., et al. (1998) Evaluation de la pré-introduction de la contraception par les implants sous-cutanés de Lévonorgestrel au Burkina Faso. Bulletin de la société médicale d'Afrique noire de langue française, 43, 79-82.

https://www.researchgate.net/publication/13459895_Evaluation_of_the_preintrodu ction_of_contraception_by_means_of_subcutaneous_levonorgestrel_implants_in_B urkina_Faso

[16] Croxatto, H.B. (2001) A New Two-Rob Lévonorgestrel Implant for Female Contraception: Basic Concepts. Gynecological Endocrinology, 15, 9-13. https://doi.org/10.1080/gye.15.s2.9.13

[17] Wysowski, D.K. and Green, L. (1995) Serious Adverse Events in Norplant Uses Reported to the Food and Drug Administration's Medwatch Spontaneous Reporting System. Obstetrics \& Gynecology, 85, 538-542.

https://www.ncbi.nlm.nih.gov/pubmed/7898829

https://doi.org/10.1016/0029-7844(94)00457-O

[18] Dugoff, L., Jones, O.W., Allen-Davis, J., Hurst, B.S. and Schlaff, W.D. (1995) As- 
sessing the Acceptability of Norplant Contraceptive in Four Patient Populations. Contraception, 52, 45-49. https://www.ncbi.nlm.nih.gov/pubmed/8521714 https://doi.org/10.1016/0010-7824(95)00123-R

[19] Chompootaweep, S., Kochagran, E., Sirisumpan, S., Tang-usaha, J., Theppitaksak, B. and Dusitsin, N. (1996) Effectiveness of Norplant Implants among Thai Women in Bangkok. Contraception, 53, 33-36. https://doi.org/10.1016/0010-7824(95)00261-8

[20] Musham, C., Darr, E.G. and Strossner, M.L. (1995) A Qualitative Study of the Perceptions of Dissatisfied Norplant Users. The Journal of Family Practice, 40, 465-470. https://www.ncbi.nlm.nih.gov/pubmed/7730770

[21] Sihvo, S., Ollila, E. and Hemminki, E. (1995) Perception and Satisfaction among Norplant Users in Finland. Acta Obstetricia et Gynecologica Scandinavica, 74, 441-445. https://www.ncbi.nlm.nih.gov/pubmed/7604687 https://doi.org/10.3109/00016349509024406

[22] Hodonou, K.A.S., Adjahoto, E.O., Kodo, K., Akpadza, K. and Baeta, S. (1999) Connaissan-ces, attitudes et pratiques des enseignants mariés de la commune de Lomé (Togo) en matière de contraception. Médecine d Afrique Noire, 46, 410-415. http://www.santetropicale.com/Resume/94606.pdf

[23] Sepou, A., Enza, J. and Nali, M.N. (2000) Les difficultés liées à l'expansion de la contraception en zones urbaines et semi-urbaines de la république centrafricaine. Médecine d Afrique Noire, 47, 74-77.

http://www.santetropicale.com/Resume/24703.pdf 


\section{Appendix. Individual Survey Form}

\section{SOCIO-DEMOGRAPHIC CHARACTERISTICS:}

Age (at the time of installation)

Age (at the time of withdrawal)

Female occupation: Housewife / / Liberal / / Student / / Employee

/____ / Other /___ Specify

Women's educational level: Primary /___ Secondary /___ University /

Out of school /

Marital status: Married /

/ Single /

Religion: Muslim /____ Christian /____ Endogenous religion /

Parity: Nulliparous / / Primiparous / / Poor (2-3)/

Multipare (4)/ // Large multipare (>4)/

Number of living children / / History of induced abortion /

HAVE YOU BEEN INFORMED ABOUT THE ADVANTAGES AND DISADVANTAGES OF JADELLE BEFORE INSTALLATION? No /_/ Yes /_/ If yes by whom?

Counsellor / Physician / / Midwife / / Nurse /

Other / Specify

HUSBAND'S/PARTNER'S CONSENT: YES / / $\mathrm{NO}$

WHAT CONTRACEPTION DID YOU PREVIOUSLY USE? MOTIVATION FOR THIS METHOD OF CONTRACEPTION:

Long, loosely constraining contraception /

Contraindication to estrogen-progestin or IUDs /

Following the advice of a health worker /

Following the advice of a friend / / Following the advice of the media 1

Other / / Specify

DURATION OF USE:

$<1-2$ years /__ 2-3 years /__ 3-4 years /__ / 4-5 years /__ / 5-6 years /

DID YOU NOTICE A CHANGE UNDER JADELLE? No /__ / Yes /__ / with Weight change: Weight gain in $\mathrm{kg} /$ ____ / Weight loss in $\mathrm{kg} /$

Menstrual cycle disorders: Amenorrhea /____ Dysmenorrhea /___ / Polymenorrhea /____ / Spaniomenorrhea /____ / Hypermenorrhea / / Others /___ _ Specify

Blood pressure abnormalities: No /__ Yes /__ / If Yes specify.

Other / / Specify

ARE YOU TAKING ANY MEDICATION SINCE THE POSE? No/ yes/

If yes which:.

REASONS FOR WITHDRAWAL: 
Desire for pregnancy / Side effects / / Expiration of efficacy

/__ / Choice of another contraceptive method / / Other /___ Speci-

fy.

DEGREE OF SATISFACTION WITH THE JADELLE:

Satisfied /__ / not satisfied /__ satisfied but adverse reactions /__ /

DO YOU PLAN TO GIVE AN IMPLANT AT THE END OF THESE 5 YEARS?

Yes /__ / No / ___ /

WOULD YOU RECOMMEND IT TO THOSE AROUND YOU ? Yes / No /__ I

DO YOU HAVE ANY COMMENTS ABOUT JADELLE ? :..................... 